\title{
AKTIVITAS ANTIOKSIDAN DAUN JAMBU AIR (SYZYGIUM SAMARANGENSE (BL.) MERR ET. PERRY) SERTA OPTIMASI SUHU DAN LAMA PENYEDUHAN
}

\author{
Ulil Albab ${ }^{1 *}$, Ratih Rizki Nirwana.2, R. Arizal Firmansyah ${ }^{3}$ \\ ${ }^{1}$ Bukit Perak Semarang Corporation, Indonesia \\ 2,3Program Studi Kimia Fakultas Sains dan Teknologi Universitas Islam Negeri Walisongo Semarang, \\ Indonesia \\ *Email: ulilalbab270894@gmail.com
}

\begin{abstract}
Abstrak
Radikal bebas merupakan suatu senyawa yang dapat menyebabkan kerusakan dan struktur pada fungsi sel yang dapat dicegah dengan antioksidan. Antioksidan dihasilkan dari ekstraksi seperti pada air seduhan teh. Penelitian ini dilakukan untuk mengetahui suhu dan waktu yang optimum dalam mengesktrak daun jambu air (Syzygium samarangene (BL.) Merr.et Perry) dan mengetahui nilai aktivitas antioksidan berupa Inhibisi Consentration $\left(\mathrm{IC}_{50}\right)$. Dalam penelitian ini metode yang digunakan berupa Rancangan Acak Lengkap (RAL) yang disusun secara terpisah dan dirancang secara faktorial (4 x 3 ) dengan 3 ulangan. Faktor pertama adalah suhu yaitu $70^{\circ} \mathrm{C}, 80^{\circ} \mathrm{C}, 90^{\circ} \mathrm{C}, 100^{\circ} \mathrm{C}$. Faktor kedua adalah waktu yaitu 5 menit, 10 menit, 15 menit. Untuk mengetahui aktivitas antioksidannya berupa IC $_{50}$ digunakan metode penangkal radikal bebas DPPH (1,1 -diphenyl-2-picylhydrazyl). Kemudian hasil absorbansi dari spektrofotometer Visibel dianalisa statistik menggunakan uji Kruskal-Wallis yang menyatakan bahwa suhu tidak berpengaruh terhadap aktivitas antioksidan ekstrak daun jambu air Semarang. Sedangkan waktu berpengaruh terhadap aktivitas antioksidan ekstrak daun jambu air Semarang. Suhu dan waktu optimum penyeduhan yang disarankan yaitu pada $70^{\circ} \mathrm{C}$ selama 5 menit dengan persen (\%) hambatan yaitu 77,46\%. Sementara itu aktivitas antioksidan ditunjukan dengan nilai IC $_{50}$ yaitu 41,01 ppm.
\end{abstract}

Kata kunci : waktu; suhu penyeduhan; daun jambu air; aktivitas antioksidan

\section{Pendahuluan}

Radikal bebas merupakan suatu molekul, atom atau beberapa grup atom yang mempunyai satu atau lebih elektron tidak berpasangan pada orbital terluarnya (Winarti, 2010). Hal ini menyebabkan radikal bebas memiliki reaktifitas yang sangat tinggi, mampu bereaksi dengan protein, lipid, karbohidrat, atau asam deoksiribonukleat (DNA) sehingga terjadi perubahan struktur dan fungsi sel. (Winarti, 2010 ; Lampe, 1999 ; Wijaya, 1996). Sehingga akan

18

Copyright (C) 2018 WJC | ISSN 2621-5985 (online) | ISSN 2549-385X (print)

Volume 1, Nomor 1, 2018 
menyebabkan berbagai macam keadaan patologik seperti penyakit karsinogenesis, proses inflamasi, juga penyakit degeneratif seperti penyakit jantung, diabetes, atherosclerosis, kanker, serta ikut berperan dalam proses penuaan (aging process) (Irene, 2000).

Antioksidan merupakan suatu senyawa yang dapat mencegah kerusakan yang disebabkan oleh radikal bebas dengan menetralkannya melalui cara menerima atau mendonorkan satu elektron untuk menghilangkan elektron tidak berpasangan yang berada pada radikal bebas (Winarsi, 2007). Antioksidan mempunyai fungsi sebagai pengawet dalam bahan pangan dengan menghambat proses oksidasi lemak/minyak. Antioksidan dalam sistem biologis berperan sebagai penangkal radikal bebas dalam tubuh sehingga dapat melawan kerusakan oksidatif yang disebabkan oleh radikal bebas. (Kesuma \& Yenrina, 2015)

Salah satu jenis tanaman lokal yang berpotensi sebagai antioksidan adalah daun jambu air varietas deli hijau. Penelitian yang telah dilakukan oleh Ragasa, dkk (2014), melaporkan terdapat senyawa baru dari isolasi daun jambu air yang kemudian dilakukan uji antimikroba dan antidiabetesnya yang menunjukkan aktivitas antimikroba dan antidiabetes yang lemah. Penelitian tersebut hanya menggunakan pelarut non polar yaitu diklorometana dan hanya meneliti antimikroba dan antidiabetes. Dilanjutkan pada penelitian yang dilakukan Adesegun, dkk (2013), melaporkan bahwa daun jambu air berpotensi sebagai antimikroba Escherichia coli. Namun penelitian tersebut terbatas pada antimikroba. Dilanjutkan penelitian yang telah dilakukan oleh Ayyida (2014) melaporkan bahwa ekstrak methanol daun jambu air semarang memiliki aktivitas antioksidan yang sangat kuat dari pada ekstrak n-heksana, sehingga berpotensi dibuat produk minuman untuk dikonsumsi sehari-hari. Akan tetapi, penelitian tentang aktivitas antioksidan pada ekstrak air daun jambu Semarang belum pernah dilakukan serta waktu dan suhu penyeduhan yang optimum sebagai pemanfaatan minuman dari daun jambu air. Metode yang digunakan pada penelitian ini radical scavenger dengan DPPH pada air seduhan daun jambu air dengan variasi suhu dan waktu. Penelitian ini diharapkan dapat memberikan informasi pada masyarakat sehingga bisa memanfaatkan daun jambu air sesuai hasil yang didapat dari penelitian mengenai waktu dan suhu penyeduhan yang optimum.

Sesuai dengan potensi dari daun jambu air yang memiliki aktivitas antioksidan dan dapat dibuat menjadi produk minuman untuk dikonsumsi dalam kehidupan sehari-hari (Ayyida, 2014 : Evangeline, dkk, 2005).

\section{Metode Penelitian}

\section{Alat dan Bahan}

Peralatan yang digunakan dalam penelitian ini adalah: Neraca analitik, gelas ukur, tabung reaksi, gelas beker, corong kaca, batang pengaduk, labu ukur, pemanas listrik, thermometer, pipet ukur, pipet volum, blender Panasonic,Freeze dryer PowerDry LL1500 dan spektrofotometer Visible Genesys 20.

Bahan yang digunakan adalah daun jambu air (Syzygium samarangene(BL.) Merr.et Perry) var. deli hijau sebagai sumber antioksidan. Bahanbahan lain: serbuk DPPH (1,1 -diphenyl-2picylhydrazyl), metanol teknis 95\%, N- heksana teknis 95\%, etil asetat teknis 95\%, metanol p.a, aquades.

Prosedur Kerja

\section{Preparasi Sampel}

Daun jambu air Semarang diambil 1,5 Kg daun segar. Kemudian diangin-anginkan di tempat yang tidak terkena cahaya matahari secara langsung hingga kering selama 7 hari. Daun kering diblender sampai halus. 


\section{Optimasi Suhu dan Waktu Penyeduhan}

Penyeduhan Daun Jambu Semarang

Aquades $50 \mathrm{~mL}$ di panaskan dengan variasi suhu yaitu $70,80,90,100^{\circ} \mathrm{C}$ dan dijaga suhunya. Kemudian dimasukkan daun jambu air kering sebanyak $1 \mathrm{~g}$ dan direndam selama variasi waktu 5, 10, 15 menit. Selama perendaman dilakukan pengadukan. Disaring dan diambil filtratnya.

\section{Uji Aktivitas Antioksidan}

Uji aktivitas antioksidan dengan metode DPPH menggunakan prosedur Blois, yaitu absorbansi yang dihitung dari $2 \mathrm{ml}$ sampel dicampur $4 \mathrm{ml}$ DPPH (Murni, 2012 : Molyneux, 2004: Dwiynati \& Nurani : 2014).

\section{a. Pembuatan larutan DPPH}

$2 \mathrm{mg}$ DPPH dilarutkan dalam $10 \mathrm{ml}$ metanol sehingga diperoleh konsentrasi 200 $\mu \mathrm{g} / \mathrm{ml}$. Diambil sebanyak $1 \mathrm{~mL}$ diencerkan dengan methanol sampai 20 ppm.

\section{b. Optimasi panjang gelombang DPPH}

$4 \mathrm{ml}$ larutan DPPH $20 \mu \mathrm{g} / \mathrm{ml}$ ditambahkan $2 \mathrm{ml}$ metanol dan dimasukkan dalam tabung reaksi. Diinkubasi dalam penangas air $37^{\circ} \mathrm{C}$ selama 30 menit. Kemudian diukur absorbansinya pada panjang gelombang 510-525 nm untuk menetukan $\lambda$ optimumnya.

\section{c. Pengujian air seduhan daun jambu air Semarang}

Air seduhan daun jambu diambil $2 \mathrm{~mL}$ ditambahkan 4 mL larutan DPPH 20 ppm ke dalam labu reaksi dan dikocok hingga homogen. Diinkubasi pada penangas air bersuhu $37^{\circ} \mathrm{C}$ selama 30 menit. Selanjutnya diukur serapannya menggunakan spektrofotometer Visible pada panjang gelombang $516 \mathrm{~nm}$. Dilakukan 3 kali pengulangan pengukuran absorbansi pada sampel baru.

\section{Penentuan $\mathrm{IC}_{50}$}

\section{Pengeringan Daun Jambu air Semarang}

Daun jambu air Semarang diambil 1,5 Kg daun segar. Kemudian diangin-anginkan di tempat yang tidak terkena cahaya matahari secara langsung hingga kering selama 7 hari. Daun kering diblender sampai halus.

\section{Perendaman Daun Jambu air Semarang}

1. Daun jambu kering sebanyak 300 gram direndam dalam pelarut n-heksana 3 liter selama 24 jam, dilakukan pengulangan 2 kali dengan pelarut baru. Filtrat diambil dan daun diangin-anginkan selama 24 jam untuk menghilangkan pelarut.

2. Daun direndam kembali dalam pelarut etil asetat 3 liter selama 24 jam, dilakukan pengulangan 2 kali dengan pelarut baru. Filtrat diambil dan daun diangin-anginkan selama 24 jam untuk menghilangkan pelarut.

3. Daun direndam kembali dalam pelarut methanol 3 liter selama 24 jam, dilakukan pengulangan 2 kali dengan pelarut baru. Filtrat diambil dan daun diangin-anginkan selama 24 jam untuk menghilangkan pelarut.

4. Daun direndam dalam pelarut air 3 liter selama 24 jam, dilakukan pengulangan 2 kali dengan pelarut baru. Filtrat diambil dan di lakukan penguapan dengan menggunakan freeze dryer.

\section{Uji Aktivitas Antioksidan}

Uji aktivitas antioksidan dengan metode DPPH dihitung dari 0,1 $\mathrm{ml}$ sampel dicampur 3,9 ml DPPH (molyneux, 2004 : Gramza, 2005).

\section{a. Pembuatan larutan DPPH}

$1 \mathrm{mg}$ DPPH dilarutkan dalam $40 \mathrm{ml}$ metanol p.a,hingga konsentrasi $25 \mu \mathrm{g} / \mathrm{ml}$ diencerkan menjadi $0,25 \mu \mathrm{g} / \mathrm{ml}$ menggunakan labu ukur $10 \mathrm{ml}$.

\section{b. Optimasi panjang gelombang DPPH}

$3,9 \mathrm{ml}$ larutan DPPH $0,25 \mu \mathrm{g} / \mathrm{ml}$ ditambahkan 0,1 ml metanol p.a, dimasukkan dalam tabung reaksi. Diinkubasi dalam penanggas air 370 C selama 30 menit. Kemudian diukur absorbansinya pada panjang gelombang 510-525 nm untuk menetukan $\lambda$ optimumnya.

\section{c. Pengujian Ekstrak air daun jambu air semarang}

20 mg ekstrak air daun jambu air semarang dilarutkan dalam $20 \mathrm{ml}$ aquades hingga 
konsentrasi $1000 \mu \mathrm{g} / \mathrm{ml}$. Dilakukan pengenceran sampai diperoleh larutan dengan konsentrasi 25 $\mu \mathrm{g} / \mathrm{ml}, \quad 50 \mu \mathrm{g} / \mathrm{ml}, \quad 75 \mu \mathrm{g} / \mathrm{ml}$ dan $100 \mu \mathrm{g} / \mathrm{ml}$. Caranya dengan memipet larutan induk berturutturut sebanyak $0,25 \mathrm{ml} ; 0,5 \mathrm{ml} ; 0,75 \mathrm{ml} ; 1 \mathrm{ml}$, dimasukkan pada labu ukur $10 \mathrm{ml}$ dan diencerkan dengan aquades hingga tanda batas. Larutan diambil masing-masing sebanyak 0,1 ml tiap konsentrasi larutan sampel. Kemudian dimasukan dalam tabung reaksi dan ditambah 3,9 ml DPPH $0,25 \mu \mathrm{g} / \mathrm{ml}$ dikocok hingga homogen. Diinkubasi dalam penanggas air $37^{\circ} \mathrm{C}$ selama 30 menit. Masing-masing diukur absorbansinya pada $\lambda 516$ $\mathrm{nm}$

\section{Teknik Analisa Data}

Data hasil absorbansi masing-masing sampel digunakan untuk mencari \% inhibisinya. Perhitungan yang digunakan adalah (Maria, 2010):

$$
\% \text { inhibisi }=\frac{A_{\text {Blanko }}-A_{\text {Sampel }}}{A_{\text {Blanko }}} \times 100 \%
$$

$\mathrm{A}_{\text {blanko }}=$ Absorbansi pada DPPH tanpa sampel

$\mathrm{A}_{\text {sampel }}=$ Absorbansi pada DPPH setelah ditambah sampel

Nilai IC $_{50}$ merupakan konsentrasi yang diperoleh pada saat \% inhibisi sebesar 50 dari persamaan $\mathrm{Y}=\mathrm{aX}+\mathrm{b}$

Pada saat \%Inhibisi=50, maka untuk menghitung nilai $\mathrm{IC}_{50}$ persamaannya menjadi:

$$
50=\mathrm{aX}+\mathrm{b}
$$

$$
X=\frac{50-b}{a}
$$

Harga X adalah $\mathrm{IC}_{50}$ dengan satuan $\mu \mathrm{g} / \mathrm{ml}$

Semua data kuantitatif optimasi suhu dan waktu dianalisis secara statistik dengan menggunakan uji Kruskal-wallis (Daniel, 1991). Data $\mathrm{IC}_{50}$ dihitung menggunakan analisis probit. Analisis statistik dilakukan dengan menggunakan program SPSS.

\section{Hasil Penelitian dan Pembahasan}

\section{A. Hasil}

\section{Preparasi Sampel}

Daun jambu air varietas deli hijau sebanyak 1,5 Kg dikeringkan di tempat yang tidak terkena cahaya matahari selama 7 hari. Pengeringan ini menghasilkan 417,46 gram. Daun kering sebanyak 117,16 digunakan untuk sampel yang diseduh. Sisa daun kering sebanyk 300 gram dimaserasi dengan pelarut n-heksana $3 \mathrm{~L}$, etil asetat $3 \mathrm{~L}$, metanol $3 \mathrm{~L}$, aquades $3 \mathrm{~L}$, masing-masing dilakukan 2 kali pengulangan. Filtrat dari aquades diambil untuk diuapkan dengan menggunakan alat freeze dryer. Penguapan ini menghasilkan 8 gram serbuk ekstrak daun jambu air. Serbuk tersebut digunakan untuk penentuan $\mathrm{IC}_{50}$.

\section{Optimasi waktu dan suhu penyeduhan}

a. Penyeduhan Sampel

Penyeduhan sampel dilakukan pada suhu $70,80,90,100^{\circ} \mathrm{C}$ dengan waktu 5, 10, 15 menit. Masing-masing penyeduhan dimasukkan sampel 1 gram daun kering. Penyeduhan ini dilakukan 3 kali pengulangan. Disaring dan diambil filtratnya. Tahap ini menghasilkan sampel penyeduhan sebanyak 36 sampel.

b. Uji Aktivitas Antioksidan

Pada uji aktivitas antioksidan ini sebelumnya dilakukan beberapa tahapan:

\section{Pembuatan Larutan DPPH}

Larutan DPPH dibuat dengan konsentrasi 20 ppm. Adapun perhitungan lengkapnya ada di lampiran 1. Larutan DPPH 20 ppm digunakan untuk menentukan optimasi suhu dan waktu pada penyeduhan sampel.

2. Optimasi Panjang Gelombang

Larutan DPPH 20 ppm diukur absorbansinya menggunakan spektrofotometer Vis dengan panjang gelombang 510 - $525 \mathrm{~nm}$. Panjang gelombang maksimal yang didapatkan yaitu $516 \mathrm{~nm}$ ditunjukkan pada tabel 1 dan gambar 1 di bawah ini: 
Tabel 1. Absorbansi Larutan DPPH 20 ppm

\begin{tabular}{rr}
\hline$\lambda(\mathrm{nm})$ & Absorbansi \\
\hline 510 & 1,065 \\
\hline 515 & 1,098 \\
\hline 516 & 1,105 \\
\hline 517 & 1,101 \\
\hline 518 & 1,096 \\
\hline 519 & 1,084 \\
\hline 520 & 1,072 \\
\hline 525 & 1,032 \\
\hline
\end{tabular}

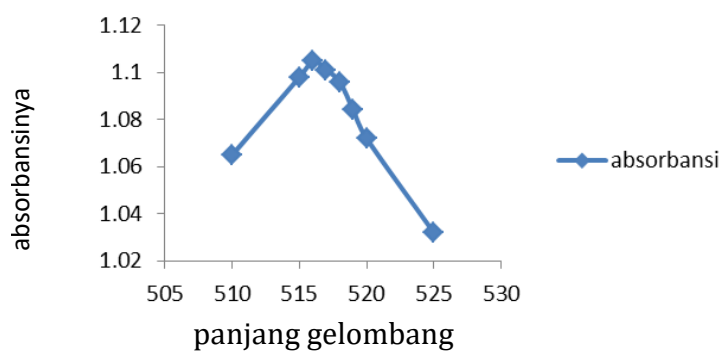

Gambar 1. Grafik Absorbansi Larutan DPPH 20 ppm

3. Pengujian Air Seduhan Daun Jambu Air

Uji ini menggunakan perbandingan $2 \mathrm{ml}$ air seduhan ditambahkan dengan $4 \mathrm{ml}$ larutan DPPH 20 ppm. Dihomogenkan dan diinkubasi pada penangas air dengan suhu $37^{\circ} \mathrm{C}$ selama 30 menit. Serta diikuti perubahan warna dari ungu menjadi kuning. Kemudian diukur absorbansinya. Absorbansi terendah terdapat pada waktu 5 menit dengan suhu $70^{\circ} \mathrm{C}$ sedangkan absorbansi tertinggi terdapat pada waktu 15 menit dengan suhu $100^{\circ} \mathrm{C}$. Hasil absorbansinya ditunjukkan pada tabel 2 dan gambar 2 di bawah ini :
Tabel 2. Absorbansi Air Seduhan

\begin{tabular}{|c|c|c|c|c|c|}
\hline $\begin{array}{c}\text { Waktu/ } \\
\text { suhu }\end{array}$ & & $70^{\circ} \mathrm{C}$ & $80^{\circ} \mathrm{C}$ & $90^{\circ} \mathrm{C}$ & $100^{\circ} \mathrm{C}$ \\
\hline \multirow{3}{*}{$\begin{array}{c}5 \\
\text { menit }\end{array}$} & 1 & 0.16 & 0.31 & 0.374 & 0.462 \\
\hline & 2 & 0.263 & 0.311 & 0.426 & 0.468 \\
\hline & 3 & 0.325 & 0.376 & 0.482 & 0.634 \\
\hline \multicolumn{2}{|c|}{$\begin{array}{c}\text { Rata-rata } \\
\text { absorban } \\
\text { si }\end{array}$} & 0.249 & 0.323 & 0.427 & 0.521 \\
\hline \multirow{3}{*}{$\begin{array}{c}10 \\
\text { menit }\end{array}$} & 1 & 0.247 & 0.355 & 0.434 & 0.543 \\
\hline & 2 & 0.295 & 0.413 & 0.498 & 0.73 \\
\hline & 3 & 0.343 & 0.445 & 0.605 & 0.986 \\
\hline \multicolumn{2}{|c|}{$\begin{array}{l}\text { Rata-rata } \\
\text { absorban } \\
\text { si }\end{array}$} & 0.295 & 0.404 & 0.512 & 0.753 \\
\hline \multirow{3}{*}{$\begin{array}{c}15 \\
\text { menit }\end{array}$} & 1 & 0.264 & 0.384 & 0.464 & 0.656 \\
\hline & 2 & 0.31 & 0.458 & 0.543 & 0.996 \\
\hline & 3 & 0.355 & 0.492 & 0.643 & 1.039 \\
\hline \multicolumn{2}{|c|}{$\begin{array}{l}\text { Rata-rata } \\
\text { absorban } \\
\text { si }\end{array}$} & 0.309 & 0.445 & 0.550 & 0.897 \\
\hline
\end{tabular}

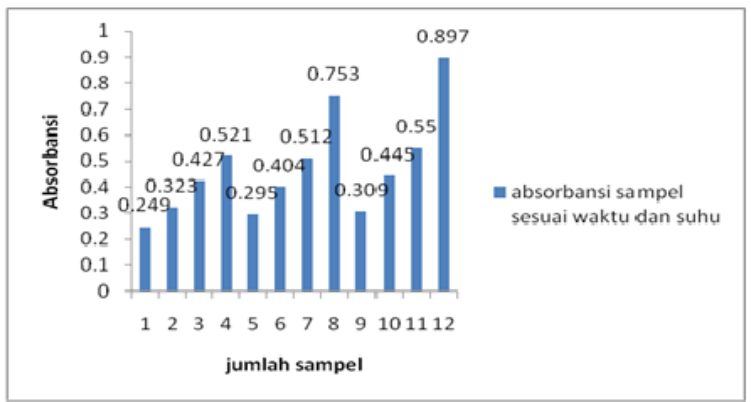

Gambar 2. Grafik Diagram Rata-rata Absorbansi Sampel

\section{Penentuan $\mathrm{IC}_{50}$}

\section{a. Pembuatan Larutan DPPH}

Larutan DPPH dibuat $25 \mathrm{ppm}$ lalu diencerkan menjadi konsentrasi 0,25 ppm digunakan untuk menentukan IC $_{50}$ pada serbuk dari ekstrak air daun jambu.

b. Optimasi Panjang Gelombang

Larutan DPPH 0,25 ppm di ukur absorbansinya menggunakan spektro-fotometer UV-Vis dengan panjang gelombang $510-525 \mathrm{~nm}$. 
Panjang gelombang maksimal yang didapatkan yaitu $516 \mathrm{~nm}$ ditunjukkan pada gambar 3 di bawah ini:

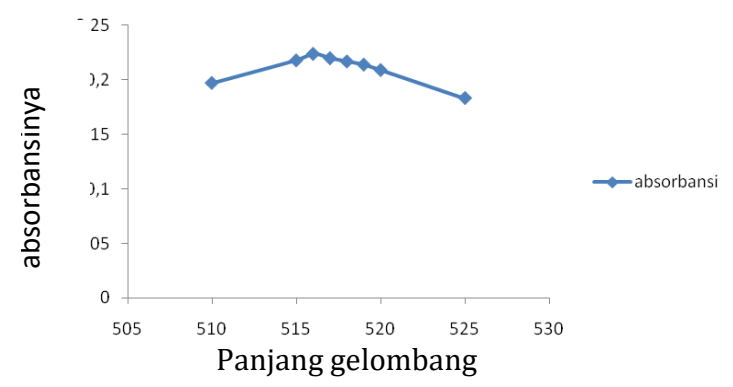

Gambar 3. Grafik Absorbansi Larutan DPPH 0,25 ppm

c. Pembuatan larutan ekstrak daun jambu air

Larutan induk dibuat dengan konsentrasi $1000 \mathrm{ppm}$. Kemudian larutan induk diencerkan menjadi konsentrasi 25, 50, 75, 100 ppm.

d. Pengujian Ekstrak Daun Jambu Air

Uji ini menggunakan perbandingan $0,1 \mathrm{ml}$ larutan ekstrak daun jambu air dengan konsentrasi 25, 50, 75, 100 ppm ditambahkan dengan 3,9 ml larutan DPPH 20 ppm. Dihomogenkan dan diinkubasi pada penangas air dengan suhu $37^{\circ} \mathrm{C}$ selama 30 menit. Serta diikuti perubahan warna dari ungu menjadi kuning.Diukur absorbansinya. Hasil absorbansinya ditunjukkan pada tabel 5 di bawah ini.

Tabel 3. Absorbansi Sampel Ekstrak Daun Jambu Air

\begin{tabular}{ccc}
\hline $\begin{array}{c}\text { Konsentrasi } \\
(\mathrm{ppm})\end{array}$ & Absorbansi 1 & $\begin{array}{c}\text { Absorbansi } \\
2\end{array}$ \\
\hline 0 & 0,224 & 0,203 \\
\hline 25 & 0,176 & 0,089 \\
\hline 50 & 0,128 & 0,056 \\
\hline 75 & 0,099 & 0,029 \\
\hline 100 & 0,055 & 0,016 \\
\hline
\end{tabular}

\section{Ekstraksi Daun Jambu Air Semarang}

Preparasi sampel daun jambu air dikeringkan dengan cara diangin-anginkan Pengeringan ini bertujuan untuk menurunkan kadar air sebanyak 8-10\% yang banyak terkandung dalam daun (Hernani, 1997). Agar senyawa-senyawa metabolit sekunder yang ada pada daun tidak rusak akibat suhu yang tinggi karena cahaya sinar matahari maka pengeringan dilakukan pada suhu kamar (Guenther, 1988 : Robinson, 1995).

Daun jambu air yang telah kering dihaluskan. Penghalusan daun dilakukan untuk memperluas permukaan zat sehingga daya difusi sampel dengan pelarut pada saat ekstraksi dapat berjalan dengan optimal. Lalu sampel disimpan di dalam wadah kedap udara dan kedap cahaya untuk menjaga mutu sampel dan mencegah kerusakan.

Pada penelitian ini sampel diekstraksi dengan cara penyeduhan dan maserasi. Menurut Astil dkk. (2001), perbedaan penyeduhan teh dapat mempengaruhi senyawa yang terkestrak dalam air seduhan. Perbedaan penyeduhannya meliputi jumlah teh dan pelarut yang digunakan, pengadukan, suhu, waktu, dan penambahan bahan lain seperti gula. Penelitian ini menggunakan daun jambu air sebanyak 1 gram yang di seduh dalam $50 \mathrm{ml}$ air. Menurut Laresolo (2008), perbandingan penyeduhan sampel:air 1:5 akan menghasilkan air seduhan dengan cita rasa yang pas. Pada umumnya formula ini sering digunakan dalam kehidupan masyarakat Indonesia. Pada penelitian ini menggunakan air destilat (aquades) karena air mempengaruhi kualitas minuman. Menurut Rohdiana (2006), air yang mengandung unsur $\mathrm{Ca} / \mathrm{Mg}$ atau air sadah akan membuat hasil ekstraksi tidak maksimal (kurang pekat).

Penyeduhan daun jambu air dilakukan dengan memvariasikan waktu dan suhu. Waktu penyeduhan yang digunakan yaitu 5,10,15 menit. Hal ini disebabkan agar ekstraksi berlangsung maksimal serta kebiasaan masyarakat Indonesia yang menyeduh daun teh sambil didiamkan hingga menunggu suhu tidak terlalu panas agar mulut dan lidah tidak kepanasan.

Suhu penyeduhan yang digunakan dalam penelitian ini yaitu $70^{\circ}, 80^{\circ}, 90^{\circ}, 100^{\circ} \mathrm{C}$. Suhu $70^{\circ} \mathrm{C}$ digunakan karena suhu tersebut merupakan suhu air hangat pada dispenser. Sebagian besar masyarakat Indonesia melakukan penyeduhan dengan menggunakan air hangat dari dispenser. Suhu $100^{\circ} \mathrm{C}$ digunakan karena merupakan titik didih air. Sedangkan suhu $80^{\circ}$ dan $90^{\circ} \mathrm{C}$ merupakan suhu tengah-tengahnya. Interval suhu menggunakan $10^{\circ} \mathrm{C}$ mengacu pada selisih suhu pada perubahan laju reaksi yang umum digunakan. 
Pada penyeduhan dilakukan 3 kali pengulangan untuk menguatkan data yang di dapatkan dalam penelitian.

Pada penentuan $\mathrm{IC}_{50}$, daun jambu diekstraksi dengan metode maserasi. Metode ini digunakan untuk mencegah terurainya metabolit yang tidak tahan dengan pemanasan. Ekstraksi dilakukan secara berturut-turut dan bertingkat yaitu pelarut $n$-heksana, etil asetat, methanol, air. Pelarut yang pertama kali digunakan adalah nheksana yang bersifat non polar dengan tujuan untuk menghilangkan lemak dan mengekstraksi senyawa-senyawa yang bersifat non polar seperti asam lemak, sterol, kumarin dan beberapa terpenoid sehingga bahan alam bebas dari lemak, selain itu juga berdasarkan pada gradien pelarut. Etil asetat bersifat semi polar digunakan untuk mengekstrak senyawa semi polar seperti steroid, triterpenoid dan saponin. Metanol yang bersifat polar digunakan untuk mengekstrak senyawa polar seperti flavonoid, glokosida, tannin dan beberapa alkaloid (Harbone: 2006). Diakhiri dengan pelarut air.

Daun kering yang dimaserasi sebanyak 300 gram dengan masing-masing pelarut nheksana, etil asetat, metanol dan air sebanyak $3000 \mathrm{ml}$ selama 24 jam dan diaduk beberapa kali. Hal ini dilakukan agar pelarut yang digunakan berdifusi ke dalam sel untuk melarutkan senyawa yang terkandung didalamnya dan larutan melewati dinding sel serta bercampur dengan cairan di sekitarnya sehingga terbentuk kesetimbangan (Samuelsson, 1999). Maserasi dilakukan sebanyak 2 kali dalam tiap pelarut dan filtrat yang diperoleh ditampung dan residu diuapkan dengan cara diangin-anginkan hingga pelarutnya menguap seluruhnya selama 24 jam. Hasil filtrat dari pelarut air diuapkan dengan menggunakan freeze dryer hingga air menguap seluruhnya. Penggunaan freeze dryer karena pelarut yang diuapkan berupa air, dimana pelarut air itu tidak bisa diuapkan menggunakan rotary vakum.

\section{Uji Aktivitas Antioksidan}

Untuk melihat pengaruh waktu dan suhu penyeduhan serta nilai aktivitas antioksidannya dilakukan dengan metode penangkal radikal bebas DPPH. Sebelumnya dilakukan penentuan optimasi 24 panjang gelombang DPPH yang bertujuan untuk mengetahui absorbansi maksimal yang menandakan panjang gelombang maksimal dari suatu larutan. Panjang gelombang maksimal memiliki kepekaan maksimal karena terjadi perubahan absorbansi yang paling besar dan juga bentuk kurva kalibrasinya memenuhi aturan lambert beer. Panjang gelombang maksimal yang didapatkan yaitu $516 \mathrm{~nm}$. Panjang gelombang 516 $\mathrm{nm}$ tergolong cahaya tampak (sinar visible) yang dapat dilihat oleh mata manusia. Sesuai dengan hukum lambert beer yang menyatakan bahwa suatu larutan berwarna dapat menyerap sinar pada panjang gelombang tampak. Absorbansi sampel air seduhan maupun sampel ekstrak daun jambu air dilakukan pada panjang gelombang 516 nm. Pengujian air seduhan dan larutan sampel ekstrak daun jambu air dengan larutan DPPH ditandai dengan perubahan warna dari ungu menjadi kuning. Perubahan warna itu menandakan bahwa senyawa itu memiliki aktivitas antioksidan. Hal itu disebabkan senyawa tersebut mendonorkan atom hidrogennya kepada radikal bebas DPPH. Reaksi yang terjadi antara DPPH dan senyawa antioksidan adalah seperti dalam gambar

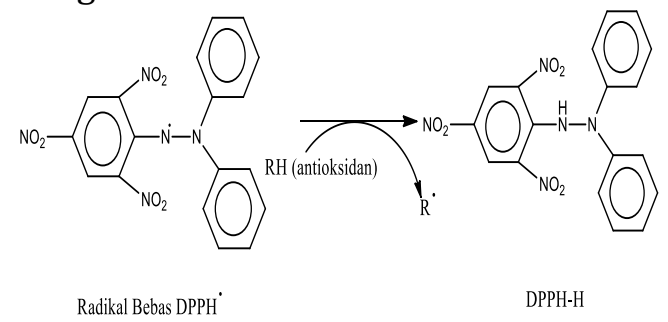

Gambar 4. Reaksi antara DPPH• dengan Antioksidan Membentuk DPPH-H. Sumber: Kesuma \& Yenrina, 2015

Penangkapan atom hidrogen mengakibatkan ikatan rangkap terkonjugasi pada DPPH berkurang sehingga terjadi penurunan intensitas warna dan penurunan absorbansi. Hal ini dapat terjadi apabila adanya penangkapan satu elektron oleh zat antioksidan yang menyebabkan tidak adanya kesempatan elektron tersebut untuk beresonansi. Resonansi senyawa DPPH dapat dilihat pada Gambar 5. 


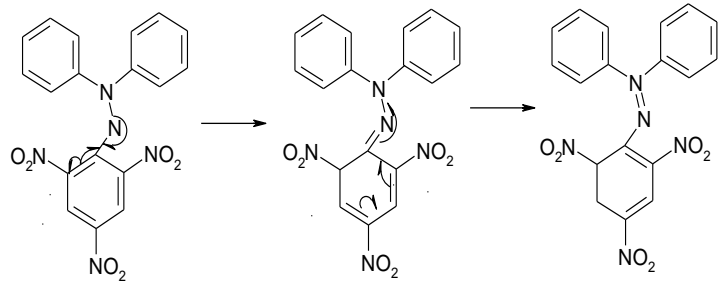

Gambar 5. Resonansi pada Struktur DPPH

Besarnya aktivitas antioksidan ditandai dengan nilai $\mathrm{IC}_{50}$, yaitu konsentrasi larutan sampel yang dibutuhkan untuk menghambat $50 \%$ radikal bebas DPPH. Data hasil pengukuran aktivitas antioksidan dari beberapa sampel dapat dilihat pada Tabel 5 dibawah ini.

Hasil analisis absorbansi penangkapan radikal bebas pada tabel 4 dihitung persen inhibasinya yang hasilnya dapat dilihat pada tabel 4 dibawah ini diagram dari \%inhibisi:

Tabel 4. Persen (\%) Inhibisi dari Absorbansi Air seduhan

\begin{tabular}{llllll}
\hline waktu/suhu & $70^{\circ} \mathrm{C}$ & $80^{\circ} \mathrm{C}$ & $90^{\circ} \mathrm{C}$ & $100{ }^{\circ} \mathrm{C}$ \\
\hline \multirow{3}{*}{5 menit } & 1 & 0.16 & 0.31 & 0.374 & 0.462 \\
\cline { 2 - 6 } & 2 & 0.263 & 0.311 & 0.426 & 0.468 \\
\cline { 2 - 6 } & 3 & 0.325 & 0.376 & 0.482 & 0.634 \\
\hline $\begin{array}{l}\text { rata-rata } \\
\text { absorbansi }\end{array}$ & 0.249 & 0.323 & 0.427 & 0.521 \\
\hline \% inhibisi & 77.46 & 70.76 & 61.13 & 52.85 \\
\hline $\begin{array}{l}10 \\
\text { menit }\end{array}$ & 1 & 0.247 & 0.355 & 0.434 & 0.543 \\
\cline { 2 - 6 } & 2 & 0.295 & 0.413 & 0.498 & 0.73 \\
\hline $\begin{array}{l}\text { rata-rata } \\
\text { absorbansi }\end{array}$ & 0.295 & 0.404 & 0.512 & 0.753 \\
\hline \%inhibisi & 73.3 & 63.43 & 53.66 & 31.85 \\
\hline $\begin{array}{l}\text { 15 } \\
\text { menit }\end{array}$ & 1 & 0.264 & 0.384 & 0.464 & 0.656 \\
\cline { 2 - 6 } & 0.31 & 0.458 & 0.543 & 0.996 \\
\hline $\begin{array}{l}\text { rata-rata } \\
\text { absorbansi }\end{array}$ & 0.309 & 0.445 & 0.550 & 0.897 \\
\hline \begin{tabular}{l} 
\%inhibisi \\
\hline
\end{tabular} & 72.03 & 59.72 & 50.22 & 18.82 \\
\hline
\end{tabular}

Tabel 4 di atas menunjukkan bahwa \% inhibisi yang terbesar pada suhu $70^{\circ} \mathrm{C}$ dengan lama penyeduhan selama 5 menit yaitu $77,46 \%$ dan yang terkecil pada suhu $100^{\circ} \mathrm{C}$ dengan lama penyeduhan selama 15 menit yaitu 18,82\%. Adapun perhitungan lengkap di lampiran 3. Secara umum semakin tinggi suhu dan lama ekstraksi suatu zat, maka kadar suatu zat tersebut juga akan semakin tinggi. Namun dilihat dari absorbansi yang dihasilkan pada sampel dari setiap perlakuan suhu dan waktu menunjukkan penurunan. Hal ini disebabkan karena senyawa metabolit sekunder flavonoid yang terkestrak pada waktu 5 menit paling optimum. Hasil tersebut sesuai dengan penelitian yang telah dilakukan Dwiyanti (2014) yang berpendapat bahwa waktu terendah merupakan waktu yang paling optimal dalam penyeduhan. Sedangkan peningkatan suhu perlakuan dapat menyebabkan kerusakan dan perubahan antioksidan terjadi secara cepat melalui tahapan: 1) hidrolisis terjadi pada ikatan glikosidik dan menghasilkan aglikon yang labil; 2) terbukanya cincin aglikon sehingga terbentuk gugus karbinol dan kalkon yang tidak berwarna sehingga terbentuk alfa-diketon yang berwarna coklat (Markakis, 1982). Terbentuknya alfadiketon menyebabkan berkurangnya jumlah gugus hidroksil yang berperan sebagai pendonor hidrogen kepada radikal bebas sehingga menurunkan nilai aktivitas antioksidan. Serta senyawa metabolit sekunder flavonoid tidak tahan terhadap suhu tinggi (Robinson, 1995).

Tabel 4 dilakukan uji persyaratan analisis (uji asumsi). Uji persyaratan analisis diperlukan guna mengetahui hipetosis dari data yang didapatkan melalui penelitian dapat dilanjutkan menggunakan statistik parametik atau statistik non parametik. Uji persyaratan analisis meliputi uji normalitas, uji homogenitas, uji linieritas, uji heterokedasitas, dan uji multikolinearitas. Dilanjutkan dengan statistik non parametik (Kruskal Wallis) (Daniel, 1991). Uji normalitas Kolmogorov-Smirnov dan Shapiro-Wilk dengan taraf signifikansi 5\% dilakukan untuk mengetahui sebaran data absorbansi berdistribusi normal atau tidak. Selain itu uji normalitas dilakukan sebagai syarat dalam menentukan uji parametrik atau nonparametrik. Tabel 5 dibawah ini merupakan hasil uji homogenitas waktu dan Tabel 6 di bawah ini menunjukkan uji homogenitas suhu. 
Tabel 5. Uji Homogenitas Variasi Waktu

\begin{tabular}{|ll|r|r|r|c|}
\hline & $\begin{array}{r}\text { Levene } \\
\text { Statistic }\end{array}$ & df1 & df2 & \multicolumn{1}{c|}{ Sig. } \\
\hline Absorbansi & Based on Mean & 1.798 & 2 & 33 & .181 \\
& $\begin{array}{l}\text { Based on Median } \\
\text { Based on Median and } \\
\text { with adjusted df }\end{array}$ & 1.078 & 2 & 33 & .352 \\
& & & 25.476 & .355 \\
& Based on trimmed \\
mean & 1.607 & 2 & 33 & .216 \\
\hline
\end{tabular}

Tabel 6. Uji Homogenitas Variasi Waktu

\begin{tabular}{|ll|r|r|r|c|}
\hline & & $\begin{array}{r}\text { Levene } \\
\text { Statistic }\end{array}$ & df1 & \multicolumn{1}{c|}{ df2 } & Sig. \\
\hline Absorbansi & Based on Mean & 10.011 & 3 & 32 & .000 \\
& $\begin{array}{l}\text { Based on Median } \\
\text { Based on Median }\end{array}$ & 5.870 & 3 & 32 & .003 \\
$\begin{array}{l}\text { and with adjusted df } \\
\text { Based on trimmed } \\
\text { mean }\end{array}$ & 5.870 & 3 & 12.754 & .010 \\
& 9.857 & 3 & 32 & .000 \\
\hline
\end{tabular}

Berdasarkan uji normalitas KolmogorovSmirnov, terdapat data yang signifikansinya lebih dari 0,05 ( $>00,05)$, dengan demikian data dianggap normal, selanjutnya akan diuji homogenitas untuk mengetahui data tersebar secara homogen atau tidak. Tabel 7 di bawah menunjukkan uji homogenitas waktu dan suhu

Tabel 7. Test of Homogeneity of Variance Waktu

\begin{tabular}{|c|c|c|c|c|c|}
\hline & & $\begin{array}{l}\text { Levene } \\
\text { Statistic }\end{array}$ & df1 & $\mathrm{df} 2$ & Sig. \\
\hline \multirow[t]{4}{*}{ Absorbansi } & \multirow{4}{*}{$\begin{array}{l}\text { Based on Mean } \\
\text { Based on Median } \\
\text { Based on Median and } \\
\text { with adjusted df } \\
\text { Based on trimmed } \\
\text { mean }\end{array}$} & 1.798 & 2 & 33 & .181 \\
\hline & & 1.078 & 2 & 33 & .352 \\
\hline & & 1.078 & 2 & 25.476 & .355 \\
\hline & & 1.607 & 2 & 33 & .216 \\
\hline & & $\begin{array}{l}\text { Levene } \\
\text { Statistic }\end{array}$ & df1 & df2 & Sig. \\
\hline \multirow[t]{4}{*}{ Absorbansi } & Based on Mean & 10.011 & 3 & 32 & .000 \\
\hline & Based on Median & 5.870 & 3 & 32 & .003 \\
\hline & $\begin{array}{l}\text { Based on Median } \\
\text { and with adjusted df }\end{array}$ & 5.870 & 3 & 12.754 & .010 \\
\hline & $\begin{array}{l}\text { Based on trimmed } \\
\text { mean }\end{array}$ & 9.857 & 3 & 32 & .000 \\
\hline
\end{tabular}

Uji homogenitas variabel waktu menunjukkan nilai signifikansi 0,181( $p>0,05)$, maka data distribusi sama atau homogen, sementara variabel suhu menunjukkan nilai signifikansi $0,000(p<0,05)$ atau data tidak homogen. Dengan demikian distribusi data ini adalah tidak sama atau tidak homogen, maka perlu dilakukan uji lanjut non-parametrik dalam hal ini adalah uji Kruskal-Wallis Test untuk mengetahui pengaruh suhu dan waktu penyeduhan daun 26 jambu air Semarang. Pada tabel 8 menunjukkan uji Kruskal-Wallis Test terhadap waktu dan tabel 9 menunjukkan uji Kruskal-Wallis Test terhadap suhu. Berikut tabel 8 :

Tabel 8. Uji Kruskal-Wallis Test terhadap Suhu

\begin{tabular}{|c|c|}
\hline & Absorbansi \\
\hline Chi-Square & 3.552 \\
Df & 2 \\
Asymp. Sig. & .169 \\
\hline
\end{tabular}

a. Kruskal Wallis Test

b. Grouping Variable: Waktu

Dari tabel 8 menunjukkan bahwa nilai Asymp signifikansi adalah 0,169 $(0,05<\mathrm{p})$, artinya adalah Ho diterima. Dengan demikian tidak terdapat perbedaan aktivitas antioksidan daun jambu air Semarang terhadap waktu.

Tabel 9. Uji Kruskal-Wallis Test terhadap Suhu

\begin{tabular}{|l|l|}
\hline & Absorbansi \\
\hline Chi-Square & 26.846 \\
Df & 3 \\
Asymp. Sig. & .000 \\
\hline
\end{tabular}

a. Kruskal Wallis Test

b. Grouping Variable: Suhu

Dari tabel 9 menunjukkan bahwa nilai Asymp signifikansi adalah 0,000 (0,05>p), artinya adalah Ha diterima. Dengan demikian terdapat perbedaan aktivitas antioksidan daun jambu air Semarang terhadap suhu.

Berdasarkan hasil penelitian diatas dengan analisa Kruskal-Wallis Test menyimpulkan bahwa pada waktu tidak terdapat perbedaan aktivitas antioksidan daun jambu air Semarang, sedangkan pada suhu terdapat perbedaan aktivitas antioksidan daun jambu air Semarang. Dikatakan tidak ada perbedaan ataupun ada perbedaan di lihat dari dignifikasi hasil yang didapatkan.

Selanjutnya menentukan $\mathrm{IC}_{50}$ dalam uji aktivitas antioksidan digunakan 4 variasi konsentrasi sampel yaitu 25, 50, 75, dan 100 ppm. Konsentrasi tersebut dipilih karena merupakan deret konsentrasi paraquat (Yuningsih, 2013). Metode paraquat bertujuan mengikat elektron bebas dari hasil fotosistem I. Hasil analisis uji aktivitas antioksidan ekstrak air daun jambu air Semarang ditunjukkan pada Tabel 
10. Hasil aktivitas antioksidan dari ekstrak kasar sampel dibandingkan dengan aktivitas antioksidan Vitamin C. Vitamin C digunakan sebagai pembanding karena Vitamin C merupakan salah satu antioksidan yang umum digunakan.

Tabel 10. Hasil Analisis Absorben Ekstrak Air Daun Jambu Air

\begin{tabular}{|c|c|c|c|c|c|}
\hline $\begin{array}{l}\text { Konsentras } \\
\text { i (ppm) }\end{array}$ & $\begin{array}{l}\text { Absorbans } \\
\text { i } 1\end{array}$ & $\begin{array}{l}\text { Absorbans } \\
\text { i } 2\end{array}$ & $\begin{array}{l}\text { \%Inhibis } \\
\text { i } 1\end{array}$ & $\begin{array}{l}\text { \%Inhibis } \\
\text { i } 2\end{array}$ & $\begin{array}{l}\text { rata-rata } \\
\text { \%inhibis } \\
\mathrm{i}\end{array}$ \\
\hline 0 & 0,224 & 0,203 & & & \\
\hline 25 & 0,176 & 0,089 & 21,428 & 56,157 & 38,793 \\
\hline 50 & 0,128 & 0,056 & 42,857 & 72,413 & 57,635 \\
\hline 75 & 0,099 & 0,029 & 55,803 & 85,714 & 70,758 \\
\hline 100 & 0,055 & 0,016 & 75,446 & 92,118 & 83,782 \\
\hline
\end{tabular}

Berdasarkan data pada tabel 10 di atas. Dilakukan analisis regresi linier hubungan antara konsentrasi ekstrak air dengan persen peredaman absorban DPPH diperoleh persamaan regresi $\mathrm{y}=$ $0,592 x+25,72$. Berdasarkan hasil yang diperoleh (Gambar 6) dari persamaan regresi linier kemudian dapat menentukan harga $\mathrm{EC}_{50}$. Dari hasil perhitungan diperoleh harga $\mathrm{IC}_{50}$ sebesar 41,01 ppm.

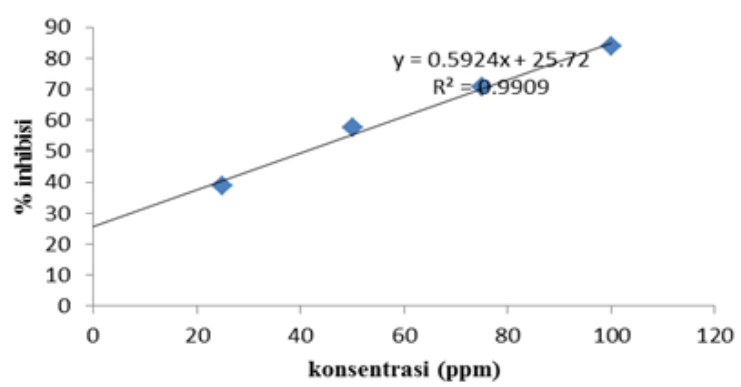

Gambar 6. Grafik regresi linear \% Peredaman Ekstrak Daun Jambu Air Semarang. Sumber: Microsift Excel

Selain menggunakan regresi linear juga menggunakan regresi non linear karena dalam beberapa penelitiannya lainnya menunjukan bahwa hubungan antara konsentrasi antioksidan dengan penangkapan radikal bebas DPPH itu non linear ((Villaño, Fernández-Pachón, Troncoso \& García-Parrilla, 2005; Locatelli, Gindro, Travaglia, Coïsson, Rinaldi \& Arlorio, 2009) uji regresi non linear dilakukan dengan aplikasi Graphapd Prims 5. Hasil analisisnya menunjukkan nilai IC $_{50}$ sebesar
181,2 ppm dengan nilai R sebesar 0,999 terdapat pada gambar 7 .

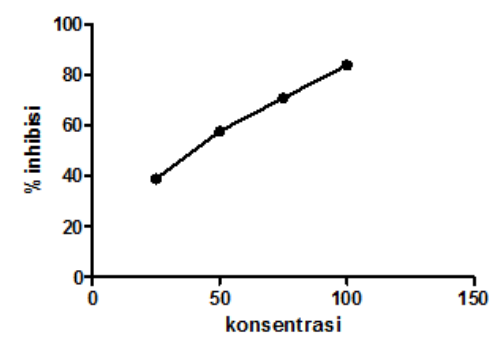

Gambar 6. Grafik Resensi Non Linier Ekstrak Air Daun Jambu Air

Nilai IC $_{50}$ pada sampel ekstrak daun jambu air Semarang menandakan bahwa senyawa metabolit sekunder (flavonoid) yang terkandung termasuk banyak. Air merupakan pelarut polar yang berarti senyawa metabolit sekunder lebih cenderung untuk larut dalam pelarut polar seperti senyawa flavonoid, fenolik. Berdasarkan pembahasan di atas didapatkan persen (\%) inhibisi paling tinggi pada suhu penyeduhan $70^{\circ} \mathrm{C}$ dengan waktu penyeduhan 5 menit yaitu 77,46\%, serta memiliki nilai aktivitas antioksidan $\left(\mathrm{IC}_{50}\right)$ yaitu 41,01 ppm. Dengan demikian ekstrak daun jambu air ini memiliki potensi yang bagus terhadap penangkal radikal bebas.

3. Uji Fitokimia

Uji fitokimia ini mengambil hasil dari penelitian yang telah dilakukan Fajar (2016) karena menggunakan sampel yang sama serta waktu penelitian yang bersamaan, berikut hasil dari uji fitokimianya: 
Tabel 11. Hasil Uji Fitokimia

\begin{tabular}{|c|c|c|c|}
\hline NO & $\begin{array}{l}\text { Senyawa } \\
\text { Kimia }\end{array}$ & $\begin{array}{ll}\text { Uji } & \text { Fitokimia } \\
\text { Sampel } & \\
\end{array}$ & $\begin{array}{l}\text { Keterangan } \\
\text { (Positif jika) }\end{array}$ \\
\hline 1 & Alkaloid & $\begin{array}{l}\text { Larutan berwana } \\
\text { hitam, tidak ada } \\
\text { endapan } \\
\text { menandakan } \\
\text { bahwa sampel (-) } \\
\text { negatif }\end{array}$ & $\begin{array}{l}\text { Terdapat } \\
\text { endapan } \\
\text { jingga }\end{array}$ \\
\hline 2 & Steroid & $\begin{array}{l}\text { Larutan berwarna } \\
\text { jingga } \\
\text { menandakan } \\
\text { bahwa sampel (+) } \\
\text { positif }\end{array}$ & $\begin{array}{l}\text { Larutan } \\
\text { berwarna } \\
\text { biru, merah, } \\
\text { hijau dan } \\
\text { jingga } \\
\end{array}$ \\
\hline 3 & Flavonoid & $\begin{array}{l}\text { Larutan berwarna } \\
\text { kuning } \\
\text { menandakan } \\
\text { bahwa sampel }(+)\end{array}$ & $\begin{array}{l}\text { Larutan } \\
\text { berwarna } \\
\text { hijau } \\
\text { kehitaman }\end{array}$ \\
\hline 4 & Tannin & $\begin{array}{l}\text { positif } \\
\text { Larutan berwarna } \\
\text { hijau kehitaman } \\
\text { menandakan } \\
\text { bahwa sampel (+) } \\
\text { positif }\end{array}$ & $\begin{array}{l}\text { Larutan } \\
\text { berwarna } \\
\text { hijau } \\
\text { kehitaman }\end{array}$ \\
\hline 5 & Saponin & $\begin{array}{l}\text { Ada busa selama } \\
15 \text { menit } \\
\text { menandakan } \\
\text { bahwa sampel }(+) \\
\text { positif }\end{array}$ & $\begin{array}{l}\text { Terdapat } \\
\text { busa stabil } \\
\text { selama } 15 \\
\text { menit }\end{array}$ \\
\hline 6 & Polifenol & $\begin{array}{l}\text { Coklat kehitaman } \\
\text { terdpat endapan } \\
\text { coklat } \\
\text { menandakan } \\
\text { bahwa sampel }(+) \\
\text { positif }\end{array}$ & $\begin{array}{l}\text { Terdapat } \\
\text { endapan } \\
\text { coklat }\end{array}$ \\
\hline 7 & Terpenoid & $\begin{array}{l}\text { Larutan berwarna } \\
\text { coklat kemerahan } \\
\text { menandakan } \\
\text { bahwa sampel }(+) \\
\text { positif }\end{array}$ & $\begin{array}{l}\text { Terbentuk } \\
\text { berwarna } \\
\text { coklat } \\
\text { kemerahan }\end{array}$ \\
\hline
\end{tabular}

\section{Keterbatasan Penelitian}

Penelitian yang telah dilakukan memiliki keterbatasan objek penelitian yaitu penelitian ini hanya terbatas pada aktivitas antioksidan pada ekstrak kasar daun jambu air serta optimasi waktu dan suhu penyeduhan yang hanya menggunakan metode penangkapan radikal bebas DPPH. Perlu dilakukan uji analit kadar total fenolat.

\section{Simpulan dan Saran}

Simpulan

Kesimpulan hasil penelitian mengenai aktivitas antioksidan daun jambu air serta suhu dan lama penyeduhan adalah sebagai berikut :

- Suhu dan lama penyeduhan yang optimum daun jambu air adalah pada $70^{\circ} \mathrm{C}$ selama 5 menit dengan persen (\%) inhibisi 77,46 \%.

- Aktivitas antioksidan ekstrak air daun jambu air menunjukkan nilai IC $_{50}$ 41,01 ppm,

Saran

- Daun jambu air bisa diteliti lebih lanjut dengan waktu penyeduhan 1, 2, 3,4, 5 menit.

- Daun jambu air bisa diteliti lebih lanjut dengan suhu penyeduhan $50,60,70,80^{\circ} \mathrm{C}$.

- Perlu digunakan larutan pembanding (asam askorbat murni, quercentin) melalui penelitian yang dilakukan secara langsung dengan grade pro analisis.

- Perlu digunakan metode penentuan aktivitas antioksidan selain DPPH misalnya FRAP, ABTS sebagai pendukung.

- Perlu dilakukan penentuan kadar total fenolat pada setiap sampel variasi suhu dan lama penyeduhan.

Perlu dilakukan analisis menggunakan GCMS atau HLPC terhadap komponen senyawa setiap ekstrak air daun jambu air di setiap variasi suhu dan lama penyeduhan.

\section{Daftar Pustaka}

Adesegun S. Adeola dkk. 2013. Essential Oil of Syzygium samarangense; A Potent Antimicrobial and Inhibitor of Partially Purified and Characterized Extracellular Protease of Escherichia coli 25922. British Journal of Pharmacology and Toxicology 4(6): 215-221

Astill C, Birch MR, Dacombe C, Philip G. Humphrey, and Martin PT. 2001. Factors affecting the caffeine and polyphenol contents of black 
and green tea infusions. J. Agric. Food Chem. Vol. 49: 5340-5347.

Ayyida Khotma. Skripsi Studi Komparasi Aktivitas Antioksidan Pada Daun Salam (Syzygium polyantum (Wight) Walp) Daun Jambu Air (Syzygium samarangense). (Semarang: Kimia FITK IAIN Walisongo. 2014)Irene Eliz. 2000. Makna Pengukuran Status Antioksidan Tubuh. Bagian Patologi Klinik. Fakultas Kedokteran UI.

Daniel, W .1991. Statistik Nonparametrik Terapan.: Gramedia. Jakarta

Dewi Murni. 2012. Isolasi Uji Aktivitas Antioksidan dan Toksisitas Menggunakan Artemia salina Leach dari Fraksi Aktif Ekstrak Metanol Daun Asa Tungga. Skripsi. Depok: Universitas Indonesia

Dwiyanti Gebi \& Hati Nurani K. Aktivitas Antioksidan Teh Rosela (Hibbiscus Sabdariffa) Selama Penyimpanan Pada Suhu Ruang, Prosiding (Vol. 5 No 1, 2014, ISSN: 2087-0922).

Gramza dkk. Tea Extracts as Free Radical Scavengers. Polish Journal of Environmental Studies (Vol. 14, No 6, 2005)

Evangeline C. Amor dkk. 2005. Spasmolytic Flavonoids from Syzygium samarangense(Blume) Merr. \& L.M. Perry, Z. Naturforsch.60 c,67-71

Guenther E. 1988. Minyak Atsiri. Jakarta: Direktorat Perguruan Tinggi

Harbone J.B. 2006. Metode Fitokimia penuntun cara modern menganalisis tumbuhan, Bandung : Penerbit ITB

Hernani Mulyono E. 1997. Pengolahan dan Penganekaragaman Hasil. Monograf No 3 Jahe. Bogor: Balitro

Laresolo B. 2008. Bagaimana cara menyeduh teh yang benar. Dari Http://www.kedaitehlaresolo.com
Maria Bintang, 2010. BIOKIMIA: Teknik Penelitian. Jakarta : Erlangga

Markaki P. 1982. Introduction in Anthocianin in Fruits, Vegetables, and Grain. New York: CRC Press.

Molyneux Philip. 2004. The use of the stable free radical diphenylpicrylhydrazyl (DPPH) for estimating antioxidant activity, Songklanakarin J. Sci. Technol, (Vol. 26 No. 2)Ragasa, 2014, Chemical constituents of Syzygium samarangense, Der Pharma Chemica, 2014, 6(3):256-260

Robinson, T. 1995. Kandungan Organik Tumbuhan Tinggi. Penerjemah: Padmawinata, K, Bandung: Penerbit ITB

Rohdiana, D. 2006. Menyeduh teh dengan 'bbm'. Lab pengolahan bahan pangan, jur tekpang $\mathrm{ft}$ unpas.www.anekaplanta.com/2007/12/26/ menyeduh-teh-dengan-bbm

Samuelsson, G. 1999. Drugs of Origin Natural: $A$ Text Book of Pharmacognosy. Sweden: Swedish Pharmaceutical Press

Sayuti, kesuma \& Rina Yenrina. 2015. Antioksidan Alami dan Sintetik, Padang: Andalas University Press.

Wijaya, A. 1996. Radikal Bebas dan Parameter Status Antioksidan. Forum Diagnosticum. Lab Klinik Prodia 1:1-12

Winarsi,Hery. 2007. Antioksidan Alami dan Radikal Bebas. Yogyakarta: Kanisiu

Winarti. 2010. Makanan Fungsional. Yogyakarta

Achmad, Rukaesih. 2004. Kimia Lingkungan. Yogyakarta: Andi

Alexander Barus, Ternala. 2002. Pengantar Limnologi. Medan: Universitas Sumatera Utara

Ashdak, Chay. 2004. Hidrologi dan Pengelolaan Daerah Aliran Sungai. Yogyakarta: Gadjah Mada University Press

Effendi, Hefni. 2003. Telaah Kualitas Air. Yogyakarta: Kanisius 
Fardiaz, Srikandi. 1992. Polusi Air dan Udara, Yogyakarta: Kanisius

Nurdalia, Ida. 2006. Kajian Dan Analisis Peluang Penerapan Produksi Bersih Pada Usaha Kecil Batik Cap: Studi Kasus Pada Tiga Usaha Industri Kecil Batik Cap di Pekalonagn. Tesis. Semarang: Program Pascasarjana Universitas Diponegoro.

Riyadi, A. L. Slamet. 1981. Ekologi Ilmu Lingkungan (Dasar-Dasar dan Pengertiannya). Surabaya: Usaha Nasional.

Silfa Millah, Lin. 2011. Pengaruh Limbah Industri Batik terhadap Komunitas Makrozoobentos sungai Simbangkulon di Kecamatan Buaran Kabupaten Pekalongan. Skripsi. Semarang: Program Studi Pendidikan Biologi Fakultas Pendidikan Matematika dan Ilmu Pengetahuan Alam IKIP PGRI.

Subagio, Puji Yosep. 2008. Tekstil Tradisional (Pengenalan Bahan dan Teknik). Jakarta: Studio Primastoria.

Supriyanto C., et.al. 2007. Analisis Cemaran Logam Berat $\mathrm{Pb}, \mathrm{Cu}$, dan $\mathrm{Cd}$ pada Ikan Air Tawar dengan Metode Spektroskopi Nyala Serapan Atom (SSA). Prosiding, Seminar Nasional III SDM Teknologi Nuklir, 21-22 November 2007. Yogyakarta: Pusat Teknologi Akselerator dan Proses Bahan.

Suriawiria, Unus. 1996. Air Dalam Kehidupan dan Lingkungan Yang Sehat. Bandung: Penerbit Alumni. 